\title{
Intravenous Pole Device
}

National Cancer Institute

\section{Source}

National Cancer Institute. Intravenous Pole Device. NCI Thesaurus. Code C50298.

A structural device designed to hang an intravenous solution bag. 